\title{
Action Learning Strategy and Students' Knowledge of Character Education Concepts in Social Studies
}

\author{
Muraina Olugbenga Omiyefa \\ Ph.D, Institute of Education, Obafemi Awolowo University, Ile-Ife, Nigeria, \\ momiyefa@oauife.edu.ng,omiyef2004@yahoo.com
}

This study investigated the effect of action learning strategy on students' knowledge of character education concepts in Social Studies. The moderating effects of level of academic ability and gender were also examined. A pretest-posttest control group, quasi-experimental design using the $2 \times 3 \times 2$ factorial matrix was adopted for the study. A multi-stage sampling procedure was adopted. The sample size was 339 Junior Secondary School II students from four randomly selected schools in Ile-Ife, Nigeria. Instructional Guide for Action Learning Strategy and Character Knowledge Test were the main instruments used in the study. Data were analysed using Analysis of Covariance to test the hypotheses at 0.05 level of significance while Scheffe post-hoc test was used to determine the source of significant difference. The result showed a significant main effect of treatment on students' knowledge of character concepts. Participants in action learning strategy performed better than those in the control group. Academic ability had significant main effects on students' knowledge. Students with the high academic ability performed better than students with moderate and low academic ability respectively. Gender had no significant main effect on students' knowledge in character education. Based on these findings, teachers of Social Studies could, therefore, adopt action learning strategy for teaching secondary school students.

Keywords: academic ability, action learning strategy, character education, character knowledge, gender, social studies

\section{INTRODUCTION}

One of the greatest challenges currently facing the Nigerian society is character deficits (Momodu, 2015). This is indeed reflected in many outcries from the public and the media. Over the years, especially since the 1970s, it has become fashionable among people to lament the decline of moral values if not the total moral degeneration in modern Nigerian society, particularly among the youths (Onyeama, 2013). This is because the youths of today have been entangled by youthful lust, pride, arrogance, disrespect, disobedience and indiscipline, degenerating to youths' uncultured behaviour (Joshua, 2012; Momodu, 2015). However, the position of various scholars has been that there is the problem of declining moral conduct in many parts of the world, Nigeria inclusive, and this has found its way into schools (Ojo, 2008). Indeed, Nigerian youths are in value conflicts and confused social world (Adetoro, 2015) as their actions seem not guided by any enviable sound value system. It is documented in literature that many Nigerians are getting involved in different immoral acts such as dishonesty, fraud and all sorts of anti-social practices (Ojo, 2008; Aimiyekagbon, Okobia \& Omole, 2013). Thus, in spite of the efforts aimed at the teaching and learning of values in schools, particularly in Social Studies, scholars like Lawal (1999), Ndan (2004), as well as Ige (2013), argued for the inability of the Nigerian educational system to produce individuals who are acceptable and useful members of the society. They observed that most Nigerian youths are involved in moral decadence, 
such as computer scam, getting-rich-quick syndrome, laziness, disrespect for the sanctity of life, early sexual activity and promiscuity, alcohol and drug abuse, among others.

To this end, the teaching of moral characters in schools has become imperative to reverse the trend and revive the glory of the past values of society. This worrisome trend possibly explains why themes on character education are often embedded in Social Studies and civic education curricula for the Junior Secondary Schools (JSS). Among such themes and concepts are the meaning of values and types of values, such as honesty, cooperation, self-reliance, integrity, contentment, self- discipline, courage, honesty and contentment. Others include importance and levels of values, factors promoting good value system such as consistency, trust, tolerance, fairness, commitment and the right attitude to work, among others (Nigerian Educational Research and Development Council - NERDC, 2007).

Social Studies as a dynamic and problem-solving discipline encompasses character formation. To Ogundiran (2012), Social Studies lays emphasis on character formation as most of the societal problems which the subject was designed to address are predominantly youth-related, either as perpetrators or as victims or both of social problems. Within the school programme, Social Studies draws its contents from social sciences, humanities, local communities, current affairs and world problems, which do not exclusively belong to one particular discipline (Akinbote, 2006). Hence, it synthesis themes from these disciplines to solve human multifaceted problems.

One of the main objectives of the current Social Studies curriculum in Nigeria is to develop young people to become responsible citizens through the cultivation of good and positive values, including moral character. Character implies the constellation of strengths and weaknesses that form and reveal who we are. Character involves a complex set of psychological characteristics, formed in part by growth in cognition that enables a person to act as a moral agent (Berkowitz \& Bier, 2004, 2005). Character is a socio-moral competence that incorporates moral action, moral values, moral personality, moral emotions, moral reasoning, moral identity, and foundational characteristics (Hunter, 2000; Bajovic, Rizzo \& Engemann, 2009). Character also includes thinking, feeling, and behaviour. It is developed from three interconnected dimensions; moral knowledge, moral feelings and behavioural skills. These three dimensions build a good character by knowing about rightness, needing it and encouraging one to perform only the acceptable things (in terms of thinking, feeling and actions).

By building a good character by knowing, character knowledge is a comprehensive approach which views character development in terms of knowing and thinking with emphasis on cognition (Vezzuto, 2004). Character knowledge involves the intellectual capacities such as critical thinking and moral reasoning (Battistich, 2013). Character knowledge gives the students what they need to know about the social vices in society and how to deal with them properly (TeAchnology, 2015). It is regrettable to note that young people these days get exposed to several thousands of negative influences through the media and their peers every day. Added to this is the fact that parents are spending less time with their children in the inculcation of moral values. Hence, students need to know how to handle these pressures, and character knowledge will give them the tools that they will be using more often than those that they learn elsewhere (TeAchnology, 2015). This is because the reason for teaching good character is to help prepare the students to face the many opportunities and unknown dangers that are in today's society.

A key factor in improving learning outcomes (including teaching for character) is choosing a teaching strategy. This is because researches continue on the usefulness of teacher-centred and student-centred instructional strategies. As a form of teacher-centred pedagogy, the traditional lectures (conventional strategy) often focus on memorisation rather than comprehension and use of information. Indeed, Raths, Hermin and Simon (1978), as well as Akinlaye, Mansaray and Ajiboye (1996) submitted that strategies such as sermonising, moralising, catechism, traditional lecture method, citation, indoctrination and other teacher-centred strategies which the teachers often use in classroom situations 
are methods that will not always work or bring successful learning outcomes as they are fraught with problems. This trend calls for new strategies to inculcate good and virtuous character through Social Studies in particular and education in general. This is perhaps necessitated the use of action learning strategy which look quite appealing for teaching character knowledge concepts in the face of the seemingly intractable era of misplaced values system being experienced in Nigeria.

The action learning strategy as developed by Revans (1983) was derived from a perspective that valuing includes a process of implementation as well as development. That is, it is important to move beyond thinking and feeling to acting (Huitt, 2004). The approach is related to the efforts of some Social Studies educators to emphasise community-based, rather than classroom-based, learning experiences. Revans (1983) largely acknowledged as the founder of action learning (McGill and Beaty, 2002) described the process of learning in the terms of the reflective inquiry process, where learning is the sum-total of attaining programmed knowledge and questioning of current insight (Stappenbelt, 2010). Marquardt (1999) as well as Marquardt and Waddill (2004), added a third element, reflection, to this model of learning to emphasise its importance. However, a variety of recent programmes have demonstrated the effectiveness of the techniques advocated by this approach (Ogunbiyi 2006; Pun 2007; Freedman, 2010; Park \& Kim 2012; Afolabi \& Akinbobola, 2012).

However, Marquardt (2004) described action learning as a strategy which explores peoples' areas of ignorance with suitable questions and real-life experiences. Robinson (2001) discovered that principles and practices of action learning have helped in developing students' involvement in learning, reflection and anatomy. Perhaps, action learning's most valuable capacity is its amazing, multiplying impact to equip individuals, especially leaders, to more effectively respond to change (Afolabi \& Akinbobola, 2012). The principles of action learning sets as outlined by Smith and O'Neil (2003) include (1) participants bring a problem to the set; (2) participants meet in small groups called 'set', (3) participants meet regularly usually over a fixed period; (4) problems are relevant to each person; (5) a supportive sharing learning environment is created within the set, sometimes with the aid of a facilitator in early stages; (6) the processes include questioning, reflection, discussion, debate and role-play; and (7) participants carry out actions between set meetings.

In an attempt to lay the foundation of action learning approach, earlier advocates (Dewey, 1939; Horney, 1950; Sullivan, 1953; Blumer, 1969; Bigge, 1971; Huitt, 1992) stressed the need to provide specific opportunities for learners to act on their values. They see valuing beyond processes of selfactualisation in which individuals consider alternatives, choose freely from among those alternatives and prize, affirm and act on their choices. They place more emphasis on the action taking inside and outside the classroom than is reflected in the moral development, analysis, and values clarification processes (Huitt, 2004). The processes of self-actualisation and problem-solving so important to the founders of action learning as one of the strategies for implementing value education. In this way, it is more related to Maslow's (1971) levels of transcendence. A problem-solving/decision-making model that can serve as a sound beginning for the action learning approach is presented by Huitt (1992) thus:

1. Input Phase: A problem is perceived, and an attempt is made to understand the situation or problem.

i. Identify the problem(s) and state it (them) clearly and concisely.

ii. State the criteria that will be used to evaluate possible alternatives to the problem as well as the effectiveness of selected solutions; state any identified boundaries of acceptable alternatives; important values or feelings to be considered, or results that should be avoided.

iii. Gather information or facts relevant to solving the problem or making a decision.

2. Processing Phase: Alternatives are generated and evaluated, and a solution is selected.

i. Develop alternatives or possible solutions.

ii. Evaluate the generated alternatives vis-à-vis the stated criteria. 
iii. Develop a solution that will successfully solve the problem (diagnose possible problems with the solution and implication of these problems; consider the worst that can happen if the solution is implemented; evaluate in terms of overall "feelings" and "values".

3. Output Phase: Includes planning for and implementing the solution.

i. Develop a plan for implementation (sufficiently detailed to allow for successful implementation).

ii. Establish methods and criteria for evaluation of implementation and success.

iii. Implement the solution.

4. Review Phase: The solution is evaluated, and modifications are made, if necessary.

i. Evaluating the implementation of the solution (an ongoing process)

ii. Evaluating the effectiveness of the solution.

iii. Modifying the solution in ways suggested by the evaluation process.

Studies have shown that action learning has a positive impact on students' abilities such as increasing their motivation and performance, as well as developing social interaction. Thus, it becomes an effective strategy to increase students' motivation and change it from the external to the internal (Joyce, Marcia \& Emily, 2009). However, researchers (Ogunbiyi 2006; Pun 2007; Freedman, 2010; Park \& Kim 2012; Afolabi \& Akinbobola, 2012) have found action learning strategy to promote significant learning outcomes among students. Indeed, studies like that of Afolabi and Akinbobola (2012) used action learning strategy in sustaining physics classroom, while Bloom (2002), Buhaminda (2003), Alexandra (2004), Allen (2005), Ogunbiyi (2006), Park and Kim (2012), as well as Sivan and Chan $(2013 ; 2014)$ only used action learning strategy on environmental education and did not determine its effect on character education concepts. These studies, thus, leave a gap which the present study is set to fill.

Furthermore, in promoting learning outcomes, scholars have argued that certain moderator variables like academic ability, gender, learning environment, age, experience, home background, locus of control, nature of school and cognitive/learning styles will play significant roles (Johnson \& Johnson, 1989). Specifically, for this study, the interplay of factors like students' academic ability and gender were considered. Academic ability, within the context of this study, refers to the students' level of academic achievement. A great deal of research related to character education posits that students who develop good character are likely to exhibit improved academic performance (Reynold \& Reynolds, 1991; Gottfredson, Gottfredson \& Hybl, 1993; Lickona, 1998; Nucci, Drill, Larson \& Browne, 2005). Studies in New Hampshire found that schools in which building students' character was a priority showed improved academic outcomes (Muscott, et al, 2008; Yeung, Mooney, Barker \& Dobia, 2009). However, studies have found that adolescents' sense of academic and moral identification positively predict their engagement in pro-social behaviours (Tirri \& Nokelainen, 2007; Roeper \& Silverman, 2009) and negatively predict their engagement in anti-social behaviours (Barriga, Morrison, Liau \& Gibbs, 2001; Wangaard \& Stephens, 2011). These conflicting reports, therefore, necessitated this study to examine the moderating effect of academic ability on students' learning outcomes in character education aspects of Social Studies when they were exposed to value analysis and action learning strategies.

Another moderator variable is gender which, in the context of this study, refers to male/female characteristics. It connotes the social and historical construction of masculine and feminine roles, behaviours, attributes, and ideologies which refer to some notion of biological sex (Imam \& Mama, 1997). This variable is germane because of the masculinity theory proposition that males because of their masculine nature tend to be arrogant, disobedient and value-free in disposition than their female counterparts (Adejumo \& Adamolekun, 1993). For instance, studies have found gender differences regarding students' misconduct with boys consistently described as more troublesome than their female peers (Kazdin, 1995; Beaman, Wheldall \& Kemp, 2007). This study, therefore, determined the 
effects of action learning instructional strategy on junior secondary school students' knowledge of character education concepts in Social Studies in Osun State, Nigeria. It also examined the moderating effect of academic ability and gender on the dependent measure of knowledge in character education.

To guide the study, the following null hypotheses were tested at 0.05 level of significance:

Ho1: There is no significant main effect of treatment (action learning strategy) on junior secondary school students' knowledge of character education concepts

Ho2: There is no significant main effect of the levels of academic ability on junior secondary school students' knowledge of character education concepts

Ho3: There is no significant main effect of gender on junior secondary school students' knowledge of character education concepts

\section{METHOD}

The study adopted pretest-posttest, control quasi-experimental design. The sample consisted of 339 participants drawn from four co-educational schools (to allow males and females) across the two local governments in Ile-Ife city, Osun State. Multi-stage sampling procedure was used to select the sample for the study. Purposive random sampling was used to select two co-educational schools from each of the two local governments in Ile-Ife city. Hence, four schools were used for the study (two schools were taught with Action Learning Strategy and two schools were taught with conventional lecture strategy). From each school that met the inclusion criteria, simple random sampling was used in selecting an intact JS II class. The selected character concepts (Honesty, Self-discipline, Integrity, Contentment, Courage and Cooperation) that were covered are also embedded in the JSII civic education and Social Studies curricula. Two validated instruments were used for the study. These are Instructional Guide for Action Learning Strategy $(\pi=0.79)$ and Character Education Knowledge Test - CEKT $(\mathrm{r}=0.81)$, the administration lasted three weeks consecutively. Students' academic ability was determined through their standardised unified promotion examination percentage average scores for grouping into high, moderate and low academic ability levels. Data were analysed using Analysis of Covariance (ANCOVA) while the Estimated Marginal Mean (EMM) aspect of ANCOVA was computed to determine the magnitude of the mean scores of the different groups and bring about the performance differences in the results in terms of the mean character knowledge scores of students with high, moderate and low academic abilities. The Scheffé post-hoc test was employed where there was significant main effect.

\section{FINDINGS}

Hypothesis 1: There is no significant main effect of treatment on junior secondary school students' knowledge of character education concepts. 
Table 1

Analysis of covariance (ANCOVA) of post-knowledge scores by treatment, gender and academic ability

\begin{tabular}{lllllll}
\hline Source & $\begin{array}{l}\text { Type III } \\
\text { Sum of } \\
\text { squares }\end{array}$ & df & $\begin{array}{l}\text { Mean } \\
\text { Square }\end{array}$ & F & Sig. & $\begin{array}{l}\text { Partial } \\
\text { Eta } \\
\text { Square }\end{array}$ \\
Corrected model & $\begin{array}{l}21498.461^{\mathrm{a}} \\
\text { Intercept }\end{array}$ & 18 & 1194.359 & 108.891 & .000 & .860 \\
Pre-knowledge & 3129.525 & 1 & 3129.525 & 285.321 & .000 & .471 \\
Main effects & 1243.456 & 1 & 1243.456 & 113.367 & .000 & .262 \\
Treatment & 1853.148 & 2 & 926.574 & 84.476 & .443 & .346 \\
Gender & 6.482 & 1 & 6.482 & & .000 & .002 \\
Academic ability & 783.553 & 2 & 391.776 & 35.719 & & .182 \\
Error & 3509.899 & 320 & 10.968 & & & \\
Total & 182206.000 & 339 & & & &
\end{tabular}

a. $\mathrm{R}$ squared $=.860$ (Adjusted $\mathrm{R}$ Squared $=.852$ ) $\quad$ *Significant at $\mathrm{P}<.05$

Table 1 shows that there is significant main effect of treatment on junior secondary school students' knowledge of character education concepts in Social Studies $\left(F_{(2,320)}=84.48 ; p<.05 ; \eta^{2}=.35\right)$. The effect size is $34.6 \%$. This reveals that there is significant difference in the post-knowledge scores of the students. Thus, hypothesis 1 was rejected. In order to determine the magnitude of the significant main effect across treatment groups, the estimated marginal means of the treatment groups is presented in Table 2

Table 2

Estimated marginal means of post-knowledge by treatment and control group

\begin{tabular}{llllll}
\hline \multirow{2}{*}{ Treatment } & $\mathrm{N}$ & Mean & Std. Error & & \multicolumn{2}{c}{ L5\% Confidence Interval } \\
\hline Action Learning Strategy & 130 & $26.004^{\mathrm{a}}$ & .375 & 25.267 & 26.740 \\
\hline Conventional Strategy & & & & & \\
\hline
\end{tabular}

Table 2 reveals that students exposed to the action learning strategy had the highest adjusted postknowledge mean score (26.00) while the students in the conventional strategy group had the least adjusted post-knowledge mean score (19.87).

Table 3

Scheffé post-hoc analysis of post-knowledge by treatment

\begin{tabular}{lllll}
\hline Treatment & $\mathrm{N}$ & Mean & Action Learning Strategy & Conventional Strategy \\
\hline Action Learning Strategy & 130 & 26.004 & & $*$ \\
\hline Conventional Strategy & 98 & 19.868 & $*$ & \\
\hline * Implies that there is a significant difference &
\end{tabular}

Table 3 indicates that the post-knowledge mean score of students exposed to action learning strategy is significantly different from their counterparts taught using the conventional strategy. This implies that the action learning strategy is the main source of significant difference in treatment.

Hypothesis 2: There is no significant main effect of the levels of academic ability on junior secondary school students' knowledge of character education concepts.

From table 1, it is evident there is significant main effect of the levels of academic ability on junior secondary school students' knowledge of character education concepts in Social Studies $\left(\mathrm{F}_{(2,320)}=\right.$ 
$\left.35.72 ; \mathrm{p}<.05 ; \eta^{2}=.18\right)$. The effect size is $18.2 \%$. Therefore, hypothesis 2 was rejected. To determine the magnitude of the significant difference, the estimated marginal means is presented in Table 4.

Table 4

Estimated marginal means of post-knowledge of students' level of knowledge of character education concepts in social studies

\begin{tabular}{llllll}
\hline & & & & \multicolumn{2}{c}{$95 \%$ Confidence Interval } \\
\cline { 5 - 6 } Academic Ability & $\mathrm{N}$ & Mean & Std. Error & Lower Bound & Upper Bound \\
\hline Low & 134 & $18.219^{\mathrm{a}}$ & .420 & 17.394 & 19.045 \\
Moderate & 136 & $21.963^{\mathrm{a}}$ & .300 & 21.373 & 22.553 \\
High & 69 & $25.979^{\mathrm{a}}$ & .664 & 24.673 & 27.286 \\
\hline
\end{tabular}

Table 4 shows that students with high academic ability had the highest adjusted post-knowledge mean score (25.98) followed by students of moderate academic ability (21.96), while the low academic ability students had the least adjusted post-knowledge mean score (18.22).

Table 5

Scheffé post-hoc analysis of post-knowledge by academic ability

\begin{tabular}{llllll}
\hline & \multicolumn{5}{c}{ Treatment } \\
\hline Academic Ability & $\mathrm{N}$ & Mean & Low & Average & High \\
\hline Low & 134 & $18.219^{\mathrm{a}}$ & & $*$ & $*$ \\
\hline Hoderate & 136 & $21.963^{\mathrm{a}}$ & $*$ & $*$ & \\
\hline
\end{tabular}

* Implies that there is a significant difference

From Table 5, the post-knowledge mean score of students with high academic ability is significantly different from students with moderate and low academic ability. Also, the post-knowledge mean score of students with moderate academic ability is significantly different from their counterparts with low academic ability. Therefore, the significant effect was mainly due to the significant contributions of the high and moderate academic abilities students.

Hypothesis 3: There is no significant main effect of gender on junior secondary school students' knowledge of character education concepts.

From table 1, is it evident that there is no significant main effect of gender on junior secondary school students' knowledge of character education concepts in Social Studies $\left(\mathrm{F}_{(1,320)}=0.59 ; \mathrm{p}>.05\right)$. Although the male students had a slightly higher post-knowledge mean score (22.21) than their female counterparts (21.89), the mean difference was not significant. Therefore, hypothesis 3 was not rejected.

\section{CONCLUSION, DISCUSSION AND SUGGESTIONS}

In conclusion, this study has established that the use of action learning strategy is effective in improving students' knowledge of character education concepts in Social Studies than the conventional strategy.

The findings revealed a significant main effect of treatment on students' knowledge of character education concepts. The findings showed that action learning strategy enhanced students' knowledge more than the conventional strategy. This result further revealed that those exposed to action learning strategy had the highest post-test knowledge mean score, than by those exposed to the conventional strategy. A possible reason for this may be because students in the experimental group were exposed to a strategy that allowed them to work collaboratively with their peers and move beyond thinking and feeling to acting on their values. Also, the involvement of learners in active learning and practice through role-playing might have contributed a lot to their highest achievement. The result of action 
learning strategy is in support of Leonard and Lang (2010), Afolabi and Akinbobola (2012), Park and Kim (2012), Sivan and Chan (2013; 2014), Jenstad and Donnelly (2015) that action learning strategy enhances proper value system in the classroom because of its powerful impact upon students' learning.

The result showed that academic ability had significant main effects on students' knowledge of character education concepts. This finding perhaps is due to the fact that the action learning strategy facilitated effective teaching and learning of various emerging themes (character education, environmental education and population education, inclusive) in Social Studies to the extent that the effect of academic ability was more pronounced on the three domains of students' learning outcomes. The result confirms the submissions of Nucci et al. (2005), Miles and Stipek (2006), Muscott, et al. (2008) and Yeung, et al. (2009) that a great deal of research related to character education posits that students who develop good character are likely to exhibit higher academic ability. The finding further corroborates the studies of Muscott, et al. (2008), Youth Frontier (2008) and Yeung, et al. (2009) that schools in which building students' character was a priority showed improved academic outcomes.

The findings of this study revealed that there was no significant main effect of gender on students' character knowledge, attitude and behavioural skills in Social Studies. This might be because, in the classroom, both male and female students were fully under the control of the subject teacher; all students received information uniformly as the teacher-directed the lesson based on the treatments. Although the male students had a slightly higher post-knowledge mean score than their female counterparts, the mean difference was not significant. This implies that irrespective of whether students are males or females, the experimental treatment was more effective than the control. This non-significant effect of gender was in support of earlier studies (Heafner, 2008; Omiyefa, 2009 \& Kehinde-Awoyele 2012), which did not observe significant gender difference in learners' knowledge and attitudes to civic issues, moral character and value education.

Based on the findings of the study, the following are therefore suggested:

1. Teachers at all levels of education should involve students in active participation by adopting action learning strategy for the teaching and learning of Social Studies.

2. The conventional mode of teaching where teachers see themselves as the supreme custodians of knowledge should be discouraged because it enhances unhealthy rivalry among learners and focuses more on memorisation rather than the comprehension and use of information for active engagement.

3. Awareness should be created among Social Studies Experts during Seminar and conferences on the need to employ the use of action learning strategies in teaching Social Studies concepts at all levels In this regard, government and Social Studies Association of Nigeria (SOSAN) should organise regular conferences and seminars using action learning instructional strategies for character development.

4. Teachers should be cognisance of the influence of students' levels of academic ability when using action learning strategy to cater for all academic categories of learners

\section{REFERENCES}

Adejumo, D. \& Ademolekun, K. (1993). Adolescent psychology. Essentials of educational foundations and counselling. A. Uba, O. Makinde, D. Adejumo and A. Aladejana. Eds. Ibadan: Claverianum Press. 197-240.

Adetoro, R. A. (2015). Issues in Social Studies and problems of nation-building in Nigeria. 4th Ed. Abeokuta: Golden Satellite Publishers Ltd. 
Afolabi, S. S. (2012). A model of transformational teacher for Nigeria national development. Proceedings for the $2^{\text {nd }}$ Annual Conference of Collaboration of Education Faculties in West Africa CEFWA. A. A. Adegoke. Ed. Lagos: Stirling-Hordan Publishers Ltd. 1-10

Afolabi, F. \& Akinbobola, A.O. (2012). Creating and sustaining action learning in physics classroom. Journal of the International Society for Teacher Education, 16(2), 22-33.

Aimiyekagbon, O. L., Okobia, O. E. \& Omole, O. O. (2013). Social Studies and citizenship education: its role in entrenching right democratic values in youths for national unity. Nigerian Journal of Social Studies, 16(1), 86-107.

Akinbote, S. R. (2006). Social Studies education in Nigerian schools. Manual on skill acquisition workshop for core subject teachers: Social Studies. E. A. Okwilagwe, S. R. Akinbote, F. V. Falaye \& P. A. Amosun. Eds. Ibadan: Osun state SUBEB in collaboration with U.I. Consultancy Services Unit. $1-18$.

Akinlaye, F. A., Mansaray, A. \& Ajiboye, J. O. (1996). Fundamentals of Social Studies teaching. Lagos: PUMARK Nigeria Education Publishers Limited

Alexandra, O. (2004). Effects of value analysis and values clarification on students' affective and cognitive achievement in environmental education. Journal of Environmental Education, 1(2), 18-32.

Allen, G. O. (2005). Value analysis, gender and students academic ability as correlate of college students' achievement in environmental education. Corner Stone Journal of Environmental Education 47(2), 13-21.

Bajovic, M., Rizzo, K. \& Engemann, J. (2009). Character education re-conceptualized for practical implementation. Canadian Journal of Educational Administration and Policy, 92, 1-23.

Barriga, A. Q., Morrison, E. M., Liau, A. K. \& Gibbs, J. C. (2001). Moral cognition: explaining the gender difference in anti-social behaviour. Merrill-Palmer Quarterly, 47, 532-562.

Battistich, V. (2013). Character education, prevention and positive youth development. Retrieved Dec. 28, 2013, from http://www.character.org/wpcontent/uploads/2011/12/ White_Paper_Battistich.pdf.

Beaman, R., Wheldall, K. \& Kemp, C. (2007). Recent research on troublesome classroom behaviour: a review. Australian Journal of Special Education, 31(1), 45-60.

Berkowitz, M. W. \& Bier, M. C. (2004). Research-based character education. The Annals of the American Academy of Political and Social Science, 59(1), 72-85.

Berkowitz, M. W. \& Bier, M. C. (2005). What works in character education: A Research-based guide for practitioners. Washington D.C: Character Education Partnership. Retrieved Dec. 29, 2013, from http://www.rucharacter.org/file/practitioners518.pdf.

Bigge, M. (1971). Positive relativism: An emergent educational philosophy. New York: Harper and Row.

Bloom, B. (2002). Values and values education strategies. Journal of Environmental Values Education, 4(12), 22-32.

Blumer, H. (1969). Symbolic interactionism: perspective and method. Englewood Cliffs. NJ: PrenticeHall.

Buhaminda, O. (2003). Teacher factors and students academic ability as correlate of students' achievement in environmental education. International Journal of Environmental Education, 2, 20-40. 
Dewey, J. (1939). Theory of Valuation. International Encyclopedia of Unified Science. Chicago, IL: University of Chicago.

Freedman, A. (2010). Using action learning for organization development and change. Retrieved Feb. 1, 2013, from http://www.wial.org/uploads/resources/ede06fe206cdb7a4f972f497d5bd74ca.pdf

Gottfredson, D., Gottfredson, G. \& Hybl, L. (1993). Managing adolescent behaviour: a multiyear, multi-school study. American Educational Research Journal, 30(1), 179-215.

Heafner, T. L. (2008). What does it mean to be a citizen? Defining Social Studies in the age of marginalization and globalization. Journal of Curriculum and Instruction, 2(1), 1-5.

Horney, K. (1950). Neurosis and human growth. New York: W. W. Norton.

Huitt, W. (2004). Values. Educational Psychology Interactive. Valdosta, GA: Valdosta State University. Retrieved Nov. 6, 2008, from http://chiron.valdosta.edu/whitt/collaffsys/values.html.

Hunter, J. D. (2000). The death of character: moral education in an age without good or evil. New York: Basic Books.

Ige, O. A. (2013). Impact of an action cybercrime prevention programme on secondary school students' learning outcomes in civic education and Social Studies. PhD. Thesis. Department of Teacher Education, University of Ibadan.

Imam, A. \& Mama, C. (1997). Sex and gender online publication. Retrieved Apr. 13, 2008, from www.naade.org.

Jenstad, L.M. \& Donnelly, M. (2015). Hearing care for elders: a personal reflection on participatory action learning with primary care providers. American Journal of Audiology, 24, 23-30.

Johnson, D. W. \& Johnson, R. T. (1989). Cooperation and competition: theory and research. Edina, $\mathrm{MN}$ : Interaction Book Company.

Joshua, E. (2012). How Nigerian youths can rebuild Nigeria. Retrieved Jan. 14, 2016 from www.informationng.com

Joyce, B., Marcia, W. \& Emily, C. (2009). Models of teaching. Boston, MA: Pearson Allyn and Bacon.

Kazdin, A. (1995). Conduct disorders in childhood and adolescence. 2nd ed. California: Sage.

Kehinde-Awoyele, A. A. (2012). Development and effects of a participatory moral education programme on pre-service teachers' knowledge of and attitude to moral concepts in Social Studies. $\mathrm{PhD}$. Thesis. Dept. of Teacher Education, University of Ibadan.

Kember, D. (2000). Action learning and action research: improving the quality of teaching and learning. London: Kogan Paul.

Lawal, M. B. (1999). Values clarification, concept mapping strategies and students' learning outcomes in junior secondary school Social Studies. PhD. Thesis. Dept. of Teacher Education. University of Ibadan.

Leonard, H.S. \& Lang, F. (2010). Leadership development via action learning. Advances in Developing Human Resources, 12, 225-240.

Lickona, T. (1998). The return of character education. Kaleidoscope: Readings in education. K. Ryan and J. M. Cooper. Eds. 185-191. Boston: Houghton Mifflin. 
Marquardt, M. J. (1999). Action learning in action: transforming problems and people for world-class organizational learning. Palo Alto: Davies-Black Publishing.

Marquardt, M. J. (2004). Harnessing the power of action learning. T and D., 58(6), 26-32.

McGill, I. \& Beaty, L. (2002). Action learning: a guide for professional, management and educational development. 2nd ed. London: Kogan Page Ltd

Miles, S. \& Stipek, D. (2006). Contemporaneous and longitudinal associations between social behaviour and literary achievement in a sample of low-income elementary school children. Child Development, 77(1), $103-117$.

Momodu, S. Oct. 6, (2015). Nigerian youths and challenge of change. This Day. Retrieved Jan. 15, 2016 from http://www.nairaland.com/2646490/nigerian-youths challenge-change.

Muscott, H., Mann, E. \& LeBrun, M. (2008). Positive behavioural interventions and supports in New Hampshire: Effects of large-scale implementation of school-wide positive behaviour support on student discipline and academic achievement. Journal of Positive Behaviour Interventions, 10(3), 190-205.

Ndan, D. E. (2004). Attributes and values for self-reliance and progress in a democratic setting: Educational implication. The Journal of the Nigerian Academy Education, 11, 54-69.

Nigerian Educational Research and Development Council - NERDC (2007). Civic education curriculum for basic 7-9. Abuja: NERDC.

Nucci, L., Drill, K., Larson, C. \& Browne, C. (2005). Preparing preservice teachers for character education in urban elementary schools. Journal of Research in Character Education, 3(2), 81-96.

Ogunbiyi, J. O. (2006). Value education and teacher-trainee environmental knowledge, attitudes and problem-solving skills in colleges of education in Ogun and Lagos States, Nigeria. PhD. Thesis. Dept. of Teacher Education. University of Ibadan.

Ogundiran, O. J. (2012). Cultural improvement in Nigeria: The value clarification strategy of social education as a tool. Nigerian Journal of Social Studies, 15(2), 100-110.

Ojo, G. T. (2008). Social Studies teachers as role models in achieving values regeneration. Nigerian Journal of Social Studies, 11(1), 39-48.

Omiyefa, M.O. (2009). Teachers' and students' perception of the relevance of Social Studies to pupils' values and moral development in Abeokuta metropolis, Ogun State. M.Ed. Dissertation. Dept. of Teacher Education. University of Ibadan.

Onyeama, H. C. (2013). Traditional African values and societal decay in Nigeria. The African Bulletin. Retrieved Apr. 5, 2013, from http://www.mediablackberry.com.

Park, K. H. \& Kim, W. (2012). Teaching clinical performance examination using action learning techniques. Korean Journal of Medical Education, 24(1), 23-30.

Passfield, R. (2002). Creating innovation and synergy through a parallel action learning structure. The Learning Organization, 9(4), 150-158.

Pun, K. F. (2007). Adopting an action-learning approach to teach industrial engineering courses in universities: The UWI experience. West Indian Journal of Engineering, 29(2), 26-40.

Raths, L. E., Harmin M. \& Simon, S. B. (1978). Values and teaching: Working with values in the classroom. 2nd Ed. Columbus, OH: Charles E. Merrill. 
Revans, R. (1983). ABC of action learning. Kent, England: Chartwell-Bratt Ltd.

Robinson, M. (2001). It works but is it action learning? Education and Training, 43(2), 64-71.

Roeper, A. \& Silverman, L. (2009). Giftedness and moral promise. Morality, ethics and gifted minds. D. Ambrose and T. Cross. Eds. Berlin, Germany: Springer.

Sivan, A. \& Chan, D. W. K. (2013). Teacher interpersonal behaviour and secondary students' cognitive, affective and moral outcomes in Hong Kong. Learning Environments Research, 16(1), 2336.

Sivan, A. \& Chan, D. W. K. (2014). Enhancing teachers' understanding of their interpersonal behaviour in the classroom: an action learning project. Journal of the International Society for Teacher Education, 18(1), 7-15.

Smith, P. A. C. \& O'Neil, J. (2003). A review of action learning literature, 1994-2000: part 1bibliography and comments. Journal of Workplace Learning, 15(2), 63-69.

Stappenbelt, B. (2010). The influence of action learning on students' perception and performance. Australian Journal of Engineering Education, 16(1), 1-11.

Sullivan, H. S. (1953). The interpersonal theory of psychiatry. New York: W. W. Norton.

TeAchnology. (2015). How Students Can Benefit From Character Education. The Online Teacher Resource. Retrieved Mar. 24, 2015, from http://www.teach-nology.com/ current trends/character_education.

Templeton Foundation. (1999). Colleges that encourage character development. Radnor, PA: The John Templeton Foundation.

Tirri, K. \& Nokelainen, P. (2007). Comparison of academically average and gifted students' self-rated ethical sensitivity. Educational Research and Evaluation, 13(6), 587-601.

Vezzuto, L. A. (2004). How young people develop character: a conceptual framework with descriptions of promising practices. Retrieved Dec. 2, 2013, from http://charactered.ocde.us/ICE/icematerials/conceptual-framework.pdf.

Wangaard, D. \& Stephens, J. (2011). Creating a culture of academic integrity. Minneapolis, MN: Search Institute.

Yeung, A., Mooney, M., Barker, K. \& Dobia, B. (2009). Does a school-wide behaviour system improve learning in primary schools? Some preliminary findings. New Horizon in Education, 57(1), 17-32.

Youth Frontiers. (2008). Youth frontier programmes. Retrieved April. 12, 2010, from www.youthfrontierprograms.org. 